\title{
ANALYSIS OF THE SURFACE MORPHOLOGY OF THE S235JRG1 STEEL AFTER AN ABRASIVE WATER JET CUTTING PROCESS
}

\section{Jana MORAVČÍKOVÁ, Daynier Rolando DELGADO SOBRINO, Peter KOŠŤÁL}

\author{
SLOVAK UNIVERSITY OF TECHNOLOGY IN BRATISLAVA, \\ FACULTY OF MATERIALS SCIENCE AND TECHNOLOGY IN TRNAVA, \\ INSTITUTE OF PRODUCTION TECHNOLOGIES, \\ Ulica JÁNA BotTu 2781/25, 91724 TRNAVA, SLOVAK REPUBLIC \\ e-mail: jana.moravcikova@stuba.sk,daynier_sobrino@stuba.sk, peter.kostal@stuba.sk \\ Received: 31.05.2018, Accepted: 26.06.2018, Published: 19.09.2018
}

\begin{abstract}
The present paper discusses the impact of the speed of an abrasive water jet cutting process on some surface properties and morphology of the S235JRG1 steel. The values of the cutting speeds used for the analysis were of 100, 150 and $200 \mathrm{~mm} \cdot \mathrm{min}^{-1}$ respectively. A contact profile method was used to analyze the surface roughness during the conducted tests. In this study, the observed surface roughness parameters were the $R a$, Rt and $R z$, respectively. At the same time, these parameters were measured in three positions, i.e.: at the inlet $(A)$, in the middle $(B)$ and at the exit position $(C)$ of the water jet nozzle with respect to the machined material. The experimental study showed that the roughness of the surface reached higher peaks and was more pronounced at the exit position $(C)$ of the water jet. Similarly, it was also concluded that a better quality of the surface was achieved at a speed of $150 \mathrm{~mm} \cdot \mathrm{min}^{-1}$.
\end{abstract}

Key words

Abrasive water jet cutting, cutting speed, surface roughness, surface morphology, steel S235JRG1

\section{INTRODUCTION}

Special machining technologies, unlike traditional ones, do not usually use mechanical means for the removal of materials. These technologies are instead based on the use of some physico-chemical or physical means to remove material, and even when these are subjected to mechanical forces, no chips appear in the process (1). This is the case of water jet technologies and water jet cutting in particular.

At present, the water jet cutting technology keeps being one of the many unconventional and environmentally friendly production technologies. Given that over the last years the demands and requirements placed on cutting processes have become stricter regarding the working environment and environment itself, the water jet cutting technology has been gaining 
terrain and increasingly become a unique opportunity to introduce automation in high performance cutting of different types of materials (2). The reminders of this paper are organized in the following headings: An Insight into the Water Jet Cutting Process, A Few Key Elements of the S235JRG1 steel, Experimental Research, Surface Roughness Analysis, Processing of the Measured Data, and finally, there is also a section of Conclusions.

\section{AN INSIGHT INTO THE WATER JET CUTTING PROCESS}

The principle behind the WJ technology lies on the use of the kinetic energy of a very thin stream of water, from which a water jet force is obtained which is capable of dividing materials of different structures and thicknesses. This technology is amongst the so called cold cutting of materials. The principle of water jet separation or cutting is based on the intense hydro-erosive action of a narrow water stream with a high flow rate coming from a water source that is compressed at the outlet of the nozzle to high pressures, usually between 210 and $620 \mathrm{MPa}$. Under these conditions, at the cutting or separation point, water no longer behaves as a liquid substance but as solid means instead. In many cases, an abrasive is added to the water medium in a powder form to improve the cutting effectiveness, and this especially in the case of harder and hard-to-machine materials.

The water jet technology is mainly used for cutting and machining materials with special mechanical properties such as titanium alloy (3), hard-to-machine materials and alloys (4), as well as for others like glass, graphite, ceramic, plastics, etc. (5The scientific community and practitioners have been constantly searching for new ways of implementing this technology into wider engineering and non-engineering areas, and this mainly based its origin and its athermic nature. If one considers the research that has been being done on these issues, most of it has mainly focused on elucidating the poorly explained and studied interaction of the water jet with different materials $(6,7)$, and also on achieving high levels of quality on the resulting surfaces of such materials (8). To this day, some technological modifications have been developed in this area: Continuous streams (NET WJ), Abrasive Water Jet (AWJ), Suspension Water Jet (SWJ) and Micro Water Jet (MWJ) to just cite the key ones. In either of the cases, the energy of the liquid, which is indeed the core technology of water jet, is enhanced by one or some of the following technology combinations: pump + water nozzle $=\mathrm{WJ}$, pump + water nozzle + acoustic actuator $=$ PWJ, pump + water nozzle + abrasive + focusing tube $=$ AWJ .

Despite its many benefits, one the key drawbacks of this technology is that it is not able to achieve the same levels of quality on the machined surface as with other more conventional technologies. In this regard and as mentioned before, the focus of researches has been centered on achieving the optimum surface quality in accordance with the input parameters set for the processing the materials, the separation of materials with a modified structure (9), and also for the turning of superalloys, or surface treatments in general (10).

On the other hand, the experimental analysis of the topography and causes of roughness and waviness of the machined surface are topics that have been examined by many authors (11, 12). However, recently, based on all these causes and an extensive analysis of the states of the art and practice, also in accordance with their own findings, the authors $(13,14)$ have presented new and so far unnoticed causes of roughness and waviness on the machined surface area. In their work, the process of measurement itself is described, and the deficiencies that occurred in the measurement quality are also listed (15).

\section{Phases of the Water Jet cutting process}

There are two main phases in a WJ cutting process:

Phase 1: The influence of the liquid pressure produces a recess which progressively changes untill an opening appears. 
Phase 2: There is a deepening of the cutting gap. The water jet cutting mechanism is dependent on the structure of material. Similarly, the cutting process is also influenced by several other peculiarities and properties of the materials (16).

Even when there are many theoretical and generally well-accepted and generalized definitions of WJ types, in practice, two basic ways of WJ are mainly used, i.e.:

- Machining with a continuous pure water jet - WJM,

- Machining with a continuous abrasive water jet - AWJM.

As illustrated in Fig. 1, the water jet cutting with an abrasive additive works on the principle of material removal by the mechanical action of a high velocity jet possessing a high kinetic energy per unit of area. The addition of the abrasive increases the mechanical effect on the removal of the material layer. If compared with other methods of material separation or cutting, such as laser, plasma, or more conventional ones like the oxy-acetylene one, the high-pressure waterjet technology does not have a thermal effect on the split material as it has been mentioned before. Besides, many other problems associated with conventional cutting can be also avoided; a simple example of this is the same deflection of cutting tools and all it means for the accuracy of the cutting process and the morphology of the materials cut (17), also the well-known variations of the cutting forces which depend, among other things, on the type of tool used (18).

\section{A FEW KEY ELEMENTS OF THE S235JRG1 STEEL}

Within the experimental work described in this paper, the authors focused on a metal sheet of $9 \mathrm{~mm}$ of thickness of S235JRG1 steel. It is a non-alloy structural steel that is suitable for parts and machines of smaller values of thickness, and may be, besides, welded and used statically or in a more slightly dynamical way. This metal sheet may be also used for various formed and welded parts, spurs, pins, levers, bolts, holders, and similar ones. Besides, this steel exhibits a guaranteed weldability. Table 1 lists the chemical composition of the analyzed steel determined by the SPECTROCAST spectrometer.

Similarly, Fig. 2 shows the S235JRG1 microstructure in a transversal and longitudinal directions. It consists of a ferrite matrix and a small fraction of perlite colonies. The microstructure reflects certain characteristics after a hot rolling process, which are indicated by the linear grain arrangement of the ferrite.

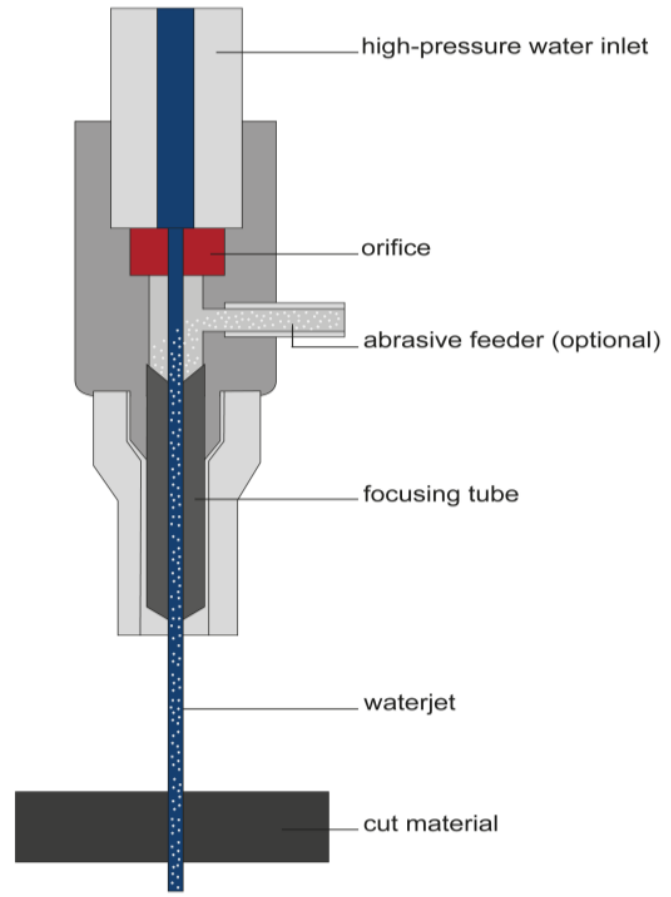

Fig. 1 Operating principle of water jet cutting (19) 


\begin{tabular}{|c|c|c|c|c|c|c|c|c|c|c|c|c|}
\hline Table 1: Chemical composition of the S235JRG1 steel \\
\hline $\mathrm{C}$ & $\mathrm{Mn}$ & $\mathrm{P}$ & $\mathrm{S}$ & $\mathrm{Cr}$ & $\mathrm{Ni}$ & $\mathrm{Al}$ & $\mathrm{Co}$ & $\mathrm{Cu}$ & $\mathrm{Ti}$ & $\mathrm{V}$ & $\mathrm{W}$ & $\mathrm{Sn}$ \\
\hline 0.08 & 0.55 & 0.031 & 0.006 & 0.07 & 0.02 & 0.054 & 0.06 & 0.12 & 0.01 & 0.07 & 0.11 & 0.011 \\
\hline
\end{tabular}
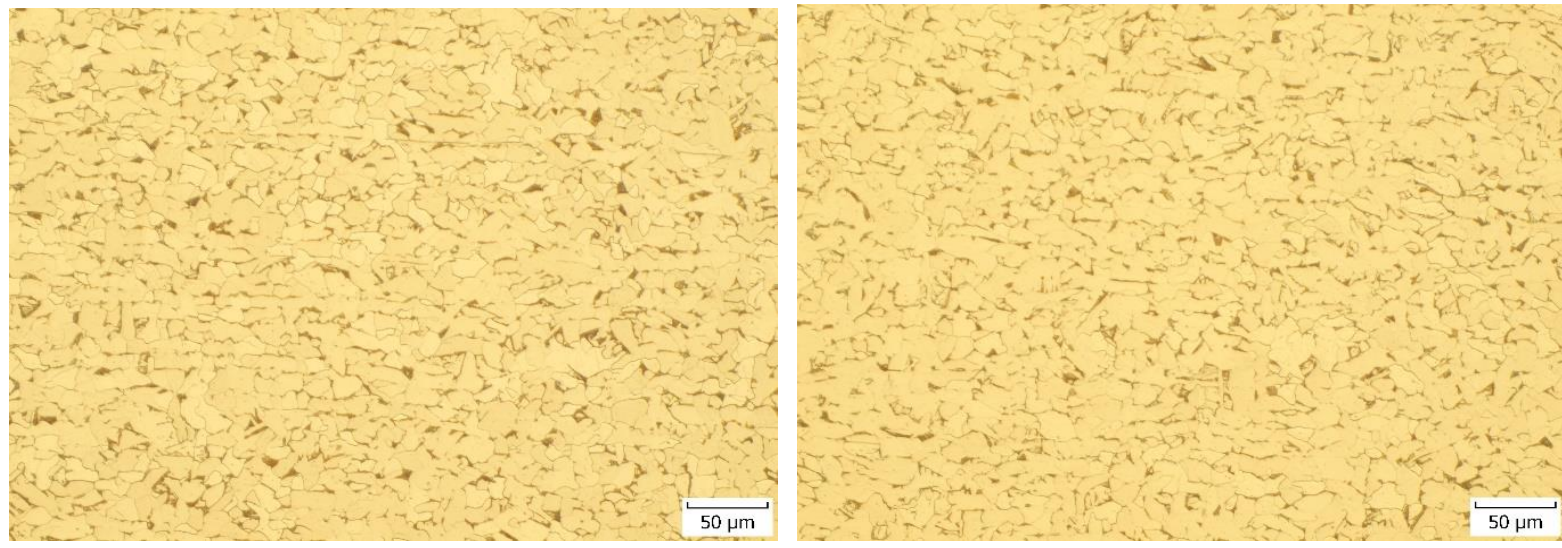

Fig. 2 Ferritic-perlite microstructure of the S235JRG1 steel sample obtained in the transversal (left) and longitudinal (right) directions.

\section{EXPERIMENTAL RESEARCH}

In this research, the material was divided by the AWJ method while varying the cutting speed. Small metal blocks of $50 \times 50 \mathrm{~mm}$ in dimension and a constant thickness of $9 \mathrm{~mm}$ were obtained from the cutting operation. For the first water jet cutting, a 50 percent of the cutting speed was set, corresponding to a $100 \mathrm{~mm} \cdot \mathrm{min}^{-1}$. The distance between the material surface and the nozzle was of $4 \mathrm{~mm}$. Further cuttings were then performed at a speed of $150 \mathrm{~mm} \cdot \mathrm{min}^{-1} 200$ $\mathrm{mm} . \mathrm{min}^{-1}$ respectively. The nozzle distance to the surface remained unchanged in all cases. The measurements for all speeds values were repeated four times, which at the end yielded a total number of 12 samples.

Fig. 3 shows a sample obtained by the WJ cutting with different areas of measurement on it.

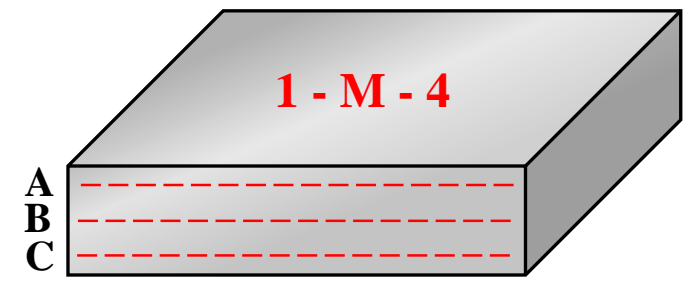

Sample denotation: 1-M-4

1 - number

M - $50 \%$ feed speed

4 - distance between the material surface and the nozzle [mm]

A - inlet position AWJM

B - middle position AWJM

C - exit position AWJM
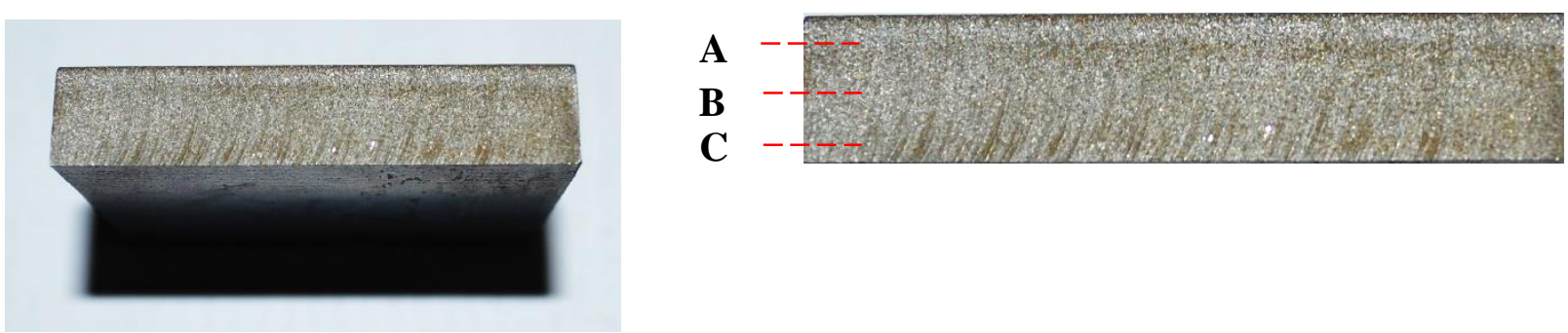

Fig. 3 Sample of the S235JRG1 steel obtained by Water Jet Cutting 


\section{SURFACE ROUGHNESS ANALYSIS}

The analysis of the roughness was carried out on the Surfcom 5000 profile. A measuring contact method with a radius of curvature of $2 \mu \mathrm{m}$ was used for the measurement. The movement speed of the contact sensor was set at $0.300 \mathrm{~mm} \cdot \mathrm{s}^{-1}$ and the measured and evaluated length was of $4 \mathrm{~mm}$. The method did not pose any risk in terms of plastic deformations, this is something of vital importance in the measuring of surfaces and has been nicely addressed by (20) in their paper. The measured values are shown in Tables 2, 3 and 4 respectively. The arithmetical mean deviation of the assessed profile $\mathrm{Ra}$, the maximum height of the profile $\mathrm{Rz}$ and the total height of the profile Rt have been all measured.

\begin{tabular}{|c|c|c|c|c|c|c|c|c|c|}
\hline \multicolumn{1}{|c|}{ Table 2: Roughness parameters on the WJ Input position - Position A } \\
\hline \multicolumn{8}{|c|}{ Rt $[\mu \mathrm{m}]$} & \multicolumn{3}{c|}{ Rz $[\mu \mathrm{m}]$} \\
\hline \multicolumn{1}{|c|}{ Speed $\left[\mathrm{mm} . \mathrm{min}^{-1}\right]$} \\
\hline No. & 100 & 150 & 200 & 100 & 150 & 200 & 100 & 150 & 200 \\
\hline 1. & 32.4 & 35.7 & 28.4 & 23.96 & 27.83 & 22.57 & 3.60 & 3.24 & 3.23 \\
\hline 2. & 36.8 & 30.1 & 48.9 & 27.16 & 17.21 & 36.76 & 4.27 & 2.43 & 5.69 \\
\hline 3. & 39.5 & 33.3 & 22.2 & 31.51 & 24.06 & 17.73 & 5.13 & 3.99 & 2.49 \\
\hline 4. & 38.6 & 22.8 & 37.5 & 26.66 & 20.52 & 27.64 & 4.33 & 3.48 & 4.66 \\
\hline Average & 36.83 & 30.48 & 34.25 & 27.322 & 22.405 & 26.175 & 4.33 & 3.285 & 4.018 \\
\hline
\end{tabular}

\begin{tabular}{|c|c|c|c|c|c|c|c|c|c|}
\hline \multicolumn{10}{|c|}{ Surface Roughness } \\
\hline & \multicolumn{3}{|c|}{$\operatorname{Rt}[\mu \mathrm{m}]$} & \multicolumn{3}{|c|}{$\mathrm{Rz}[\mu \mathrm{m}]$} & \multicolumn{3}{|c|}{$\mathrm{Ra}[\mu \mathrm{m}]$} \\
\hline \multirow[b]{2}{*}{ No. } & \multicolumn{9}{|c|}{ speed $\left[\mathrm{mm} \cdot \mathrm{min}^{-1}\right]$} \\
\hline & 100 & 150 & 200 & 100 & 150 & 200 & 100 & 150 & 200 \\
\hline 1. & 41.8 & 36.2 & 31.2 & 31.82 & 27.14 & 24.52 & 5.81 & 4.93 & 4.02 \\
\hline 2. & 40.4 & 21.8 & 51.9 & 26.85 & 18.70 & 40.12 & 4.64 & 4.57 & 7.69 \\
\hline 3. & 35.1 & 52.5 & 30.9 & 28.21 & 39.22 & 22.87 & 4.64 & 7.64 & 4.86 \\
\hline 4. & 37.3 & 29.5 & 40.5 & 30.77 & 22.37 & 30.10 & 5.28 & 3.99 & 5.40 \\
\hline Average & 38.65 & 35,00 & 38.625 & 29.412 & 26.858 & 29.403 & 5.09 & 5.283 & 5.492 \\
\hline
\end{tabular}

\begin{tabular}{|c|c|c|c|c|c|c|c|c|c|c|}
\hline \multicolumn{1}{|c|}{ Table 4: Roughness parameters on the WJ exit position - Position C } \\
\hline \multicolumn{1}{|c|}{ Rt $[\mu \mathrm{m}]$} & \multicolumn{3}{c|}{ Rz $[\mu \mathrm{m}]$} \\
\hline \multicolumn{1}{|c|}{ Surface Roughness } \\
\hline No. & 100 & 150 & 200 & 100 & 150 & 200 & 100 & 150 & 200 \\
\hline 1. & 37.5 & 42.6 & 38.6 & 26.29 & 30.75 & 29.58 & 4.48 & 6.48 & 4.96 \\
\hline 2. & 53.7 & 30 & 37.1 & 41.58 & 20.5 & 19.46 & 7.58 & 4.21 & 3.42 \\
\hline 3. & 57.5 & 49 & 46.1 & 33.79 & 28.54 & 23.95 & 6.63 & 5.8 & 4.48 \\
\hline 4. & 36.1 & 43.2 & 85.8 & 26.95 & 28.18 & 52.54 & 4.76 & 5.12 & 11.14 \\
\hline Average & 46.20 & 41.20 & 51.90 & 32.153 & 26.993 & 31.383 & 5.863 & 5.403 & 6.000 \\
\hline
\end{tabular}




\section{PROCESSING OF THE MEASURED DATA}

Fig. 4 recreates the behavior of the measured roughness parameters $\mathrm{Rt}, \mathrm{Rz}$ and $\mathrm{Ra}$, depending on the speed.

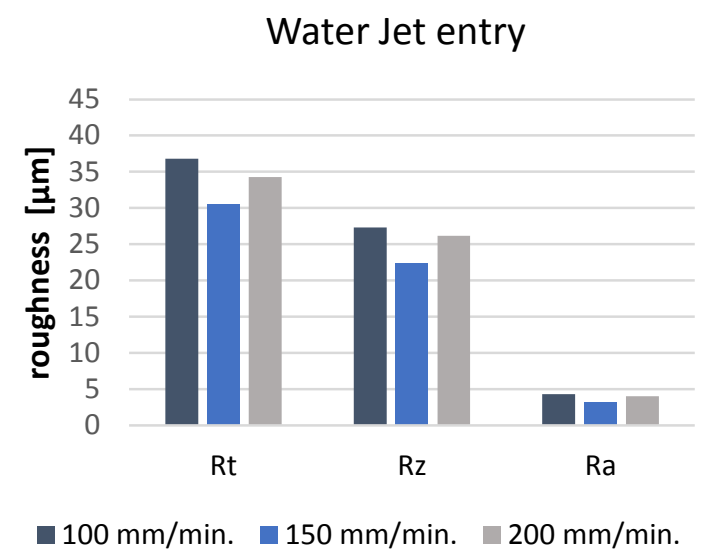

a)

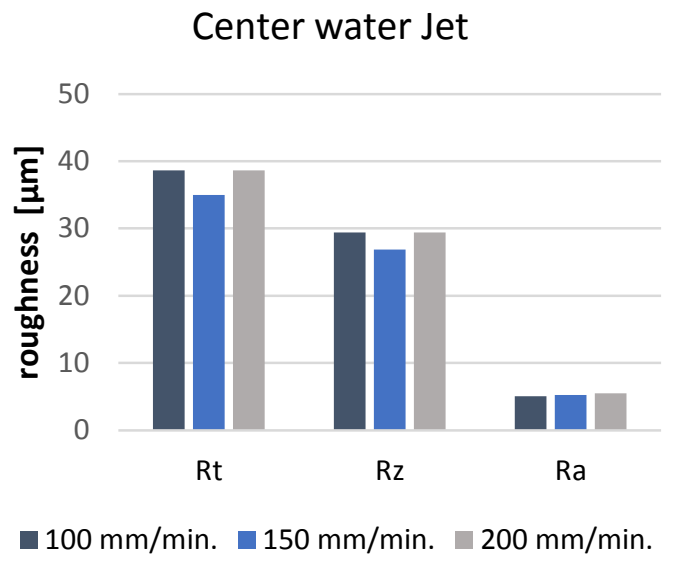

b)

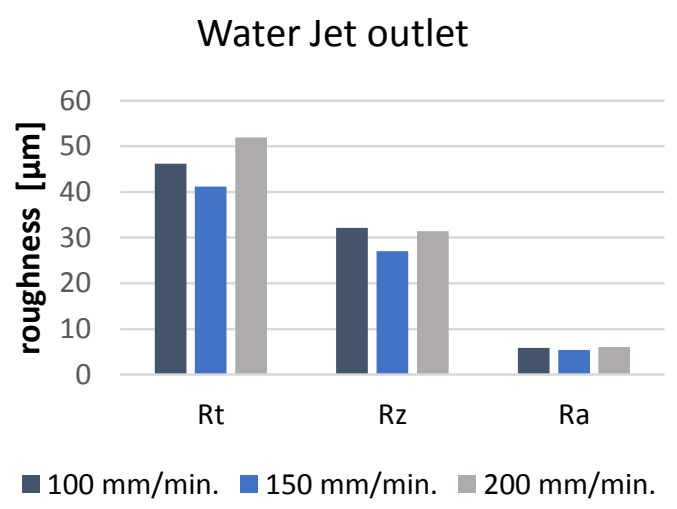

c)

Fig. 4 Graphical dependence of the roughness parameters a) input position AWJM - position A b) middle position AWJM c) exit position AWJM.

Next, Fig. 5 to 7 show the recorded values of the measurement of the profile roughness using the Surfcom 5000. The movement speed of the contact sensor was set at $0.300 \mathrm{~mm} . \mathrm{s}^{-1}$ and the evaluated length was of $4 \mathrm{~mm}$. The graphical information appearing bellow in the figures only refers to those of the position $\mathrm{C}$ given that these were the ones reflecting the highest roughness values during the measurements, see also the previous Fig. 3 for a better understanding.

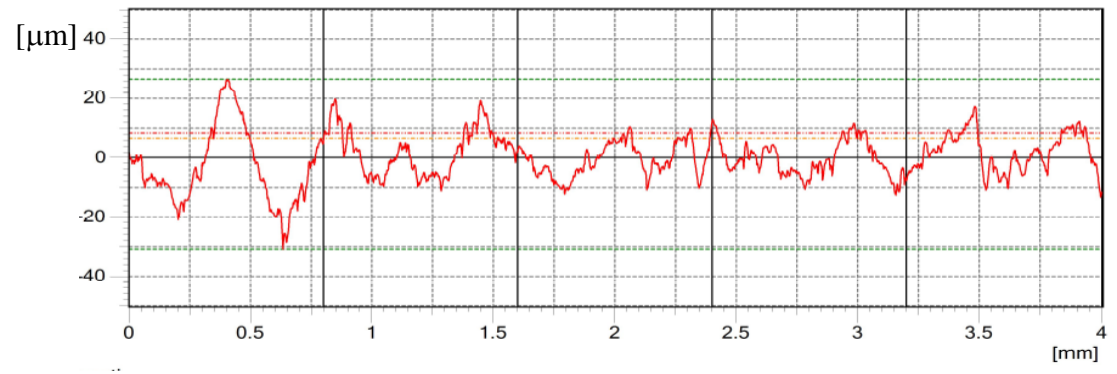

Fig. 5 Roughness profile at the WJ exit position - Position C-feed speed $100{\mathrm{~mm} . \mathrm{min}^{-1}}^{-1}$ 


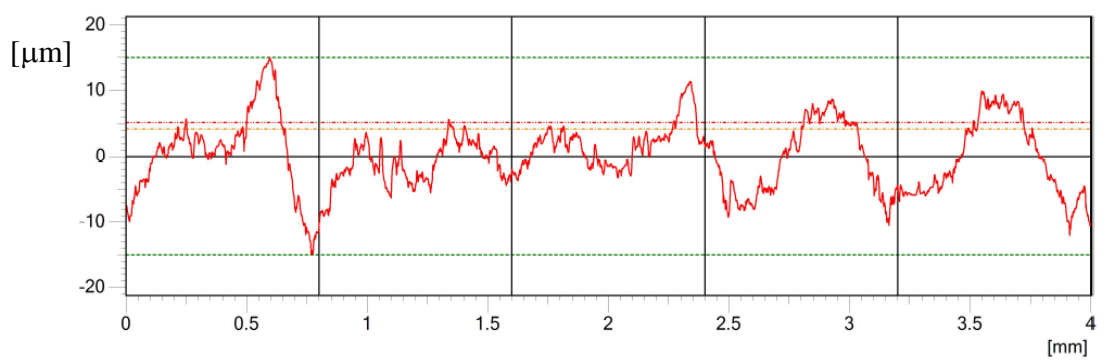

Fig. 6 Roughness profile at the WJ exit position - Position C - feed speed $150 \mathrm{~mm} . \mathrm{min}^{-1}$

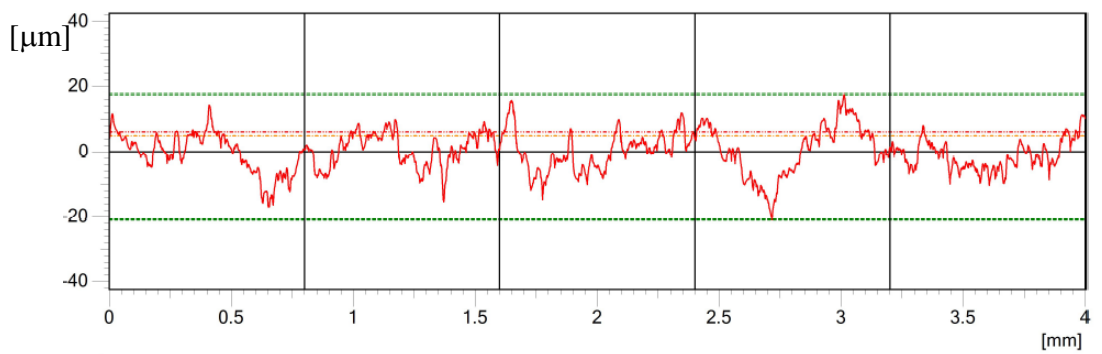

Fig. 7 Roughness profile at the WJ exit position - Position C - feed speed $200 \mathrm{~mm} . \mathrm{min}^{-1}$

\section{CONCLUSIONS}

This paper covered and analyzed WJ technology and its key advantages and drawbacks with respect to other more traditional methods; emphasis was made on the WJ cutting process. More specifically, the paper focused on the impact of the cutting speed of a WJ cutting process on the surface morphology of a S235JRG1 steel part. It was determined that the best values of surface roughness parameters of this part were achieved at a nozzle movement speed of 150 $\mathrm{mm} \cdot \mathrm{min}^{-1}$. Comparable roughness values were obtained at speeds of 100 and $200 \mathrm{~mm} \cdot \mathrm{min}^{-1}$ respectively. In order to evaluate the quality of the surface, several parameters of the profiles, i.e. Ra, Rt and Rz were monitored and analyzed. The results of this study contribute to further clarify some elements in the possibilities and ways of using this technology for this specific type of material. However, these same results should not be applied or assumed as equivalent if analyzing other steels or materials.

\section{Acknowledgement}

This contribution is a part of the project Technical research and development infrastructure for contact and non-contact measurement methods, ITMS 26210120020, the Operational Program Research and Development financed by the European Regional Development Fund.

This contribution has been also supported by the KEGA-021STU-4/2018 Project of Development of a laboratory for the design and maintenance of production systems supported by the use of Virtual Reality. All this support is gratefully acknowledged.

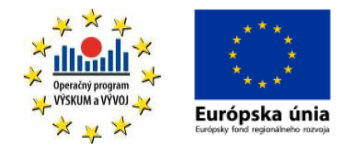




\section{References:}

1. VELÍŠEK, K., KOŠŤÁL, P., PECHÁČEK, F. 2006. Stroje a zariadenia pre špeciálne technológie. (Machines and equipment for special technologies.) Bratislava: STU Publishing House. ISBN 80-227-2364-9.

2. SOBOTOVÁ, L., KARKOVÁ, M. 2012. Kvalita rezacej vody pri technológií delenia materiálov vodným lúčom 2012. (Cutting water quality in waterjet cutting technology 2012.) [online]. [cit.10.10.2016]. Available on the Internet: https://www.sjf.tuke.sk/transferinovacii/pages/archiv/transfer/24-2012/pdf/125-128.pdf

3. HLOCH, J. S. et al. 2014. Abrasive waterjet (AWJ) titanium tangential turning evaluation. Metalurgija, 53, pp. 537-540.

4. CÁRACH, J. et al. 2016. Tangential turning of Incoloy alloy 925 using abrasive water jet technology, Int. J. Adv. Manuf. Technol. 82, pp. 1747-1752.

5. LISSEK, F. et al. 2016. Online -monitoring for abrasive waterjet cutting of CFRP via acoustic emission: Evaluation of machining parameters and work piece quality due to burst analysis. In: Procedia Engineering, pp. $67-76$.

6. HASHISH, M., SOUTH, A. 1991. Optimization Factors in Abrasive - Waterjet Machining. J. Eng. Ind. 1.

7. WANG, J., GUO, D. M. 2002. A predictive depth of penetration model for abrasive waterjet cutting of polymer matrix composites. J. of Mat. Proc. Tech., 121(2-3), pp. 390-394.

8. HREHA, P. et al. 2015. Determination of vibration frequency depending on abrasive mass flow rate during abrasive water jet cutting. Int. J. Adv. Manuf. Technol., 77, pp. 763-774.

9. KUMAR, R. et al. 2017. Surface integrity analysis of abrasive water jet - cut surfaces of friction stir welded joints. Int. J. Adv. Manuf. Technol.

10. SRIVASTAVA, M., et al. 2016. Potential of using water jet peening as a surface treatment process for welded joints. In: Procedia Engineering, pp. 472-480.

11. HLOCH, S., GOMBAR, M., RADVANSKÁ, A. 2007. Non-linear modelling and evaluation of pressure and traverse rate influence to acoustic sound pressure level at abrasive waterjet machining. Int. J. Autom. Control, 1.

12. JURISEVIC, B., BRISSAUD, D., JUNKAR, M. 2004. Monitoring of abrasive water jet (AWJ) cutting using sound detection. Int. J. Adv. Manuf. Technol. 24, 733-737.

13. MOMBER, A. W., KOVACEVIC, R. 1998. Principles of Abrasive Water Jet Machining. London: Springer-Verlag.

14. KULEKCI, M. K. 2002. Processes and apparatus developments in industrial waterjet applications. Int. J. Mach. Tools Manuf. 42, pp. 1297-1306.

15. HLOCH, S., VALÍČEK, J. 2012. Topographical anomaly on surfaces created by abrasive waterjet. Int. J. Adv. Manuf. Technol. 59, pp. 593-604.

16. MIČIETOVÁ, A. 2001. Nekonvenčné metódy obrábania. (Unconventional machining methods.) Žilina: ŽU Publishing House. (In Slovak)

17. BÍLEK, O., SMETKA, P., BAĎUROVÁ, J. 2017. Deflection of complex geometry cutting tools. Manufacturing Technology, 17(6), pp. 830-836. ISSN 1213-2489.

18. LANCEA, C. 2004. Considerations about the Cutting Force Variation when Milling with Ball-Nose Tools. Academic Journal of Manufacturing Engineering, 2, p. 55-59. ISSN: 1583-7904

19. Water jet cutting machinas, information on http://www.imes-icore.de/esp/productos-industrialessistema-cnc-html/equipos-corte-agua-html/conocimientos-especializados-html.html

20. KOWALIK, M. et al. 2016. Plastic Deformations of Measured Object Surface in Contact with Undeformable Surface of Measuring Tool. In: MEASUREMENT SCIENCE REVIEW, 16(5), pp. 254-259.

\section{ORCID:}

Jana Moravčíková

Daynier Rolando Delgado Sobrino

Peter Košt’ál
0000-0002-6281-3969

$0000-0001-9253-6141$

0000-0001-6622-6174 